\title{
Marinomonas polaris sp. nov., a psychrohalotolerant strain isolated from coastal sea water off the subantarctic Kerguelen islands
}

Correspondence Sisinthy Shivaji shivas@ccmb.res.in

\author{
Pratima Gupta, ${ }^{1}$ Preeti Chaturvedi, ${ }^{1}$ Suman Pradhan, ${ }^{1}$ Daniel Delille ${ }^{2}$ \\ and Sisinthy Shivaji ${ }^{1}$ \\ ${ }^{1}$ Centre for Cellular and Molecular Biology, Uppal Road, Hyderabad 500 007, India \\ ${ }^{2}$ Université $\mathrm{P}$ and $\mathrm{M}$ Curie (Paris 6), Observatoire Océanologique de Banyuls, CNRS URA \\ 2071, F-66650 Banyuls sur Mer, France
}

Two aerobic, psychrohalotolerant, motile bacterial isolates, $\mathrm{CK} 13^{\top}$ and $\mathrm{CK} 16$, isolated from sea-water samples collected off the subantarctic Kerguelen island, were characterized by using a polyphasic taxonomic approach. On the basis of $16 \mathrm{~S}$ rRNA gene sequence data, the strains were $99.6 \%$ similar and exhibited $93-97 \%$ similarity with the seven recognized species of Marinomonas. The most closely related species were Marinomonas pontica and Marinomonas primoryensis, with 97 and $96 \%$ similarity at the $16 \mathrm{~S}$ rRNA gene sequence level, respectively. DNA-DNA hybridization values between strain $\mathrm{CK} 13^{\top}$ and $M$. pontica and $M$. primoryensis were only 58 and $40 \%$, respectively. The major fatty acids present in strain $\mathrm{CK}_{13^{\top}}$ were iso- $\mathrm{C}_{16: 0}$, $\mathrm{C}_{16: 0}, \mathrm{C}_{16: 1} \omega 7 \mathrm{c}$ and $\mathrm{C}_{18: 1} \omega 7 \mathrm{c}$. The DNA G+C content of strain $\mathrm{CK}_{13^{\top}}$ was $41 \cdot 2 \mathrm{~mol} \%$. Phosphatidylethanolamine and phosphatidylglycerol were identified as the predominant phospholipids. All the above characteristics support the affiliation of strain $\mathrm{CK} 13^{\top}$ to the genus Marinomonas. Phylogenetic analysis and phenotypic and genotypic distinctiveness confirmed that strains $\mathrm{CK}_{13}{ }^{\top}$ and $\mathrm{CK} 16$ are members of a novel species of the genus Marinomonas, for which the name Marinomonas polaris sp. nov. is proposed. The type strain is $\mathrm{CK}_{13}{ }^{\top}$ (=MTCC $6645^{\top}=$ DSM $\left.16579^{\top}=J C M 12522^{\top}\right)$.
The genus Marinomonas was created to accommodate two reclassified Alteromonas species, namely Alteromonas communis and Alteromonas vaga (Baumann et al., 1972), as these species formed a separate and distinct rRNA branch when compared with the other true alteromonads (Van Landschoot \& De Ley, 1983). Species assigned to the genus Marinomonas are rod-shaped, motile, lack amylase, gelatinase and lipase activities and have the ability to utilize glycerol, lactate and $m$-hydroxybenzoate, but not butyrate or valerate as carbon sources. To date, seven species of Marinomonas have been described, Marinomonas communis, M. vaga, M. mediterranea, M. primoryensis, $M$. ushuaiensis, M. pontica and M. aquimarina (Baumann et al., 1972; Solano \& Sanchez-Amat, 1999; Romanenko et al., 2003; Ivanova et al., 2005; Macian et al., 2005; Prabagaran et al., 2005). In the present study, a bacterial strain $\mathrm{CK} 13^{\mathrm{T}}$, isolated from sea water off the subantarctic Kerguelen island, has been identified as representing a novel species of the genus Marinomonas.

The GenBank/EMBL/DDBJ accession number for the 16S rRNA gene sequence of strain $\mathrm{CK}_{1}{ }^{\top}$ is AJ833000.

A supplementary table detailing the cellular fatty acid content of strain $\mathrm{CK} 13^{\top}$ and related Marinomonas species is available in IJSEM Online.
Strains $\mathrm{CK} 13^{\mathrm{T}}$ and $\mathrm{CK} 16$ were isolated from sea water collected at a site located $110 \mathrm{~km}$ south-west of the subantarctic Kerguelen islands $\left(50^{\circ} 40^{\prime} \mathrm{S} 68^{\circ} 25^{\prime} \mathrm{E}\right)$. The strains were isolated along with 45 other pure strains by plating $200 \mu \mathrm{l}$ sea water on marine agar 2216 (Difco) and incubating the plates at $12{ }^{\circ} \mathrm{C}$ for 10 days. Marine agar was used for growth and maintenance of the strains and for the determination of the phenotypic and chemotaxonomic characteristics as listed in Table 1 and Supplementary Table S1 (see IJSEM Online). Luria-Bertani medium $[1 \cdot 0 \%(\mathrm{w} / \mathrm{v})$ tryptone, $0 \cdot 5 \%(\mathrm{w} / \mathrm{v})$ yeast extract and $1 \cdot 0 \%(\mathrm{w} / \mathrm{v}) \mathrm{NaCl}]$ was used to test the salt tolerance of the organism. The shape, size and motility of the cells was ascertained using a Leitz Diaplan phase-contrast microscope with an oilimmersion objective $(\times 100)$. The sensitivity of the cultures to antibiotics was checked by using antibiotic discs (Himedia). For biochemical tests, cultures were grown at $22^{\circ} \mathrm{C}$ on marine agar 2216 and tests were performed as described by Baumann et al. (1984) and Smibert \& Krieg (1994). Utilization of various carbon compounds as sole carbon sources was tested in liquid minimal medium containing $\left(1^{-1}\right) 1 \mathrm{~g}$ ammonium chloride, $0 \cdot 075 \mathrm{~g}$ dipotassium hydrogen phosphate, $1.45 \mathrm{~g}$ calcium chloride, $30.0 \mathrm{~g}$ sodium chloride, $6 \cdot 15 \mathrm{~g}$ magnesium chloride, $0.75 \mathrm{~g}$ 
Table 1. Phenotypic characteristics that differentiate Marinomonas polaris sp. nov. CK13 $3^{\top}$ from other Marinomonas species

Strains: 1, M. polaris $\mathrm{CK} 13^{\mathrm{T}} ; 2$, M. pontica LMG $22531^{\mathrm{T}}$; 3, M. primoryensis IAM $15010^{\mathrm{T}}$; 4, M. ushuaiensis MTCC $6143^{\mathrm{T}}$ (data from Prabagaran et al., 2005); 5, M. mediterranea ATCC 700492 ${ }^{\mathrm{T}}$ (Solano \& Sanchez-Amat, 1999); 6, M. communis DSM 5604 ${ }^{\mathrm{T}}$ (Baumann et al., 1972); 7, M. vaga ATCC $27119^{\mathrm{T}}$ (Baumann et al., 1972); 8, M. aquimarina CECT $5080^{\mathrm{T}}$ (Macian et al., 2005). Data for taxa 1-3 are from this study. All of these Marinomonas species are Gram-negative, rod-shaped, motile bacteria which test negative for gelatin hydrolysis and for denitrification and test positive for glucose and mannose utilization. Strains $\mathrm{CK} 13^{\mathrm{T}}$ and $\mathrm{CK} 16$ share similar phenotypic characteristics. + , Positive; -, negative; ND, no data available; w, weakly positive; v, variable.

\begin{tabular}{|c|c|c|c|c|c|c|c|c|}
\hline Characteristic & 1 & 2 & 3 & 4 & 5 & 6 & 7 & 8 \\
\hline Pigment & Absent & Absent & Absent & Absent & Melanin-like & Absent & Absent & Absent \\
\hline \multicolumn{9}{|l|}{ Growth at: } \\
\hline $4{ }^{\circ} \mathrm{C}$ & + & + & + & + & - & - & - & - \\
\hline $37^{\circ} \mathrm{C}$ & + & - & - & - & - & + & ND & + \\
\hline $\mathrm{pH}$ range for growth & $6 \cdot 0-10 \cdot 0$ & $6 \cdot 0-10 \cdot 0$ & $6 \cdot 0-9 \cdot 5$ & $7 \cdot 0-12 \cdot 5$ & ND & $7 \cdot 0-11 \cdot 0$ & ND & ND \\
\hline $\mathrm{NaCl}$ requirement & - & + & + & + & + & + & ND & + \\
\hline $\mathrm{NaCl}$ tolerance $(\%)$ & 11 & 10 & 8 & 6 & 6 & 6 & ND & 10 \\
\hline Lipase & - & - & - & - & + & - & - & - \\
\hline Amylase & - & - & - & + & - & - & - & - \\
\hline Phosphatase & + & + & + & + & ND & - & ND & ND \\
\hline Simmon's citrate test & + & + & - & - & ND & - & ND & ND \\
\hline Nitrate reduction & - & - & - & - & + & - & - & - \\
\hline \multicolumn{9}{|c|}{ Carbon source utilization: } \\
\hline L-Alanine & - & + & - & ND & ND & + & + & + \\
\hline L-Arginine & + & + & + & - & ND & + & $\mathrm{V}$ & ND \\
\hline Benzoate & - & - & - & + & ND & - & - & ND \\
\hline Butyrate & - & - & - & - & ND & - & - & ND \\
\hline Cellobiose & + & + & + & - & ND & - & ND & - \\
\hline Citrate & - & - & - & ND & + & + & + & + \\
\hline D-Galactose & + & - & - & ND & ND & ND & ND & - \\
\hline Erythritol & + & - & - & - & ND & - & + & ND \\
\hline Glycerol & + & + & + & - & + & + & + & - \\
\hline L-Glycine & + & - & - & ND & ND & - & - & + \\
\hline$m$-Hydroxybenzoate & - & - & - & + & - & + & + & ND \\
\hline Lactose & + & + & - & + & ND & - & - & - \\
\hline L-Lysine & - & - & - & - & ND & + & $\mathrm{V}$ & - \\
\hline Malate & - & - & - & - & + & + & + & + \\
\hline Maltose & + & + & + & $\mathrm{W}$ & - & ND & $\mathrm{ND}$ & ND \\
\hline L-Rhamnose & - & + & - & - & ND & ND & + & - \\
\hline D-Ribose & + & - & + & - & ND & - & ND & $\mathrm{W}$ \\
\hline Sorbitol & + & - & - & - & + & + & + & - \\
\hline Succinate & - & - & - & - & + & + & + & + \\
\hline L-Threonine & + & - & - & ND & ND & + & ND & - \\
\hline
\end{tabular}

potassium chloride and $0 \cdot 028 \mathrm{~g}$ ferrous sulphate, supplemented with $0 \cdot 2 \%$ of the filter-sterilized carbon source (Romanenko et al., 2003). Fatty acid methyl esters were prepared from cells grown at $22^{\circ} \mathrm{C}$ for $48 \mathrm{~h}$ according to the method of Sato \& Murata (1988) and analysed as described by Kiran et al. (2004). The modified method of Bligh \& Dyer (1959) was employed to extract polar lipids and molybdenum blue reagent was used to detect lipids containing phosphate esters. DNA was isolated and the DNA G+C content was determined as described by Gupta et al. (2004). DNA-DNA hybridization was performed by the membrane filter method of Tourova \& Antonov (1987) as described by Shivaji et al. (1992). M. pontica LMG $22531^{\mathrm{T}}$ and $M$. primoryensis IAM $15010^{\mathrm{T}}$ were used as controls in biochemical tests, in the identification of fatty acids and polar lipids and in DNA-DNA hybridization experiments.

The 16S rRNA gene was amplified from genomic DNA, purified and sequenced as described by Shivaji et al. (2000). To determine the phylogenetic affiliation of the novel strains, the almost-complete $16 \mathrm{~S}$ rRNA gene sequence (1475 bp) of strain $\mathrm{CK} 13^{\mathrm{T}}$ was aligned with related species of the genus Marinomonas using CLUSTAL W (Thompson et al., 1994). Pairwise evolutionary distances were computed using the DNADIST program with the Kimura two-parameter model as developed by Kimura (1980). Phylogenetic trees were 
constructed using the neighbour-joining and UPGMA treemaking algorithms from the PHYLIP package (Felsenstein, 1993). The stability among clades of the phylogenetic tree was assessed by performing 1000 replicates and analysing the dataset using the programs SEQBOOT, DNADIST, NEIGHBOR and CONSENSE from the PHYLIP package.

Marine isolates $\mathrm{CK} 13^{\mathrm{T}}$ and CK16 are aerobic, Gramnegative, halotolerant, rod-shaped and motile bacteria which are able to grow between 4 and $37^{\circ} \mathrm{C}$. Colony appearance on marine agar is smooth, non-pigmented and convex. Morphological features and some biochemical properties characteristic of members of the genus Marinomonas, such as lack of amylase, lipase and gelatinase activities, the presence of catalase activity, but weak oxidase activity and the utilization of glycerol, but not butyrate, are also exhibited by both novel strains (Table 1). The fatty acid content, with iso- and branched-chain fatty acids $\mathrm{C}_{16: 0}(6 \cdot 2 \%)$, iso $\mathrm{C}_{16: 0}$ $(18 \cdot 5 \%), \mathrm{C}_{16: 1} \omega 7 c(26.5 \%)$ and $\mathrm{C}_{18: 1} \omega 7 c(40 \cdot 0 \%)$ as the major fatty acids, and the presence of phosphatidylethanolamine and phosphatidylglycerol as the major phospholipid constituents also indicate that $\mathrm{CK} 13^{\mathrm{T}}$ and CK16 are similar to the previously described Marinomonas species (Romanenko et al., 2003; Ivanova et al., 2000, 2005; Prabagaran et al., 2005) (see Supplementary Table S1 in IJSEM Online). Other morphological and biochemical characteristics that differentiate $\mathrm{CK} 13^{\mathrm{T}}$ from recognized Marinomonas species are given in Table 1 and in the description of the novel species. Fatty acid content was similar in $\mathrm{CK}_{13}^{\mathrm{T}}$, M. pontica LMG $22531^{\mathrm{T}}$ and M. primoryensis IAM $15010^{\mathrm{T}}$ (see Supplementary Table S1 in IJSEM Online).

Phylogenetic analysis of the almost-complete 16S rRNA gene sequence (1475 nucleotides) of strain $\mathrm{CK} 13^{\mathrm{T}}$ using the neighbour-joining algorithm confirmed the affiliation of this marine strain to the genus Marinomonas. The phylogenetic tree based on the above analysis showed that strain $\mathrm{CK} 13^{\mathrm{T}}$ is within the species cluster comprising the genus Marinomonas and forms a clade with $M$. primoryensis IAM $15010^{\mathrm{T}}$ and M. pontica LMG $22531^{\mathrm{T}}$, with a bootstrap value of $>90 \%$ (Fig. 1). The close relationship between $\mathrm{CK} 13^{\mathrm{T}}$, $M$. primoryensis and $M$. pontica was further evident from a BLAST analysis of the 16S rRNA gene sequence of CK13 ${ }^{\mathrm{T}}$, which exhibits 97 and $96 \%$ similarity with $M$. primoryensis and M. pontica, respectively. Despite the high similarity at the 16S rRNA gene sequence level, in terms of DNA-DNA hybridization strain $\mathrm{CK} 13^{\mathrm{T}}$ shares only 58 and $40 \%$ relatedness with $M$. pontica LMG $22531^{\mathrm{T}}$ and M. primoryensis IAM $15010^{\mathrm{T}}$, respectively. Further, $\mathrm{CK} 13^{\mathrm{T}}$ differs from these closely related species in regard to a number of phenotypic characteristics (Table 1). According to the criteria recommended for discriminating species (Stackebrandt \& Goebel, 1994), strain $\mathrm{CK} 13^{\mathrm{T}}$, which exhibits $>3 \%$ difference at the $16 \mathrm{~S}$ rRNA gene sequence level with all previously described Marinomonas species, $<70 \%$ relatedness in DNA-DNA hybridization with the closely related species $M$. pontica and $M$. primoryensis and which also differs in phenotypic traits

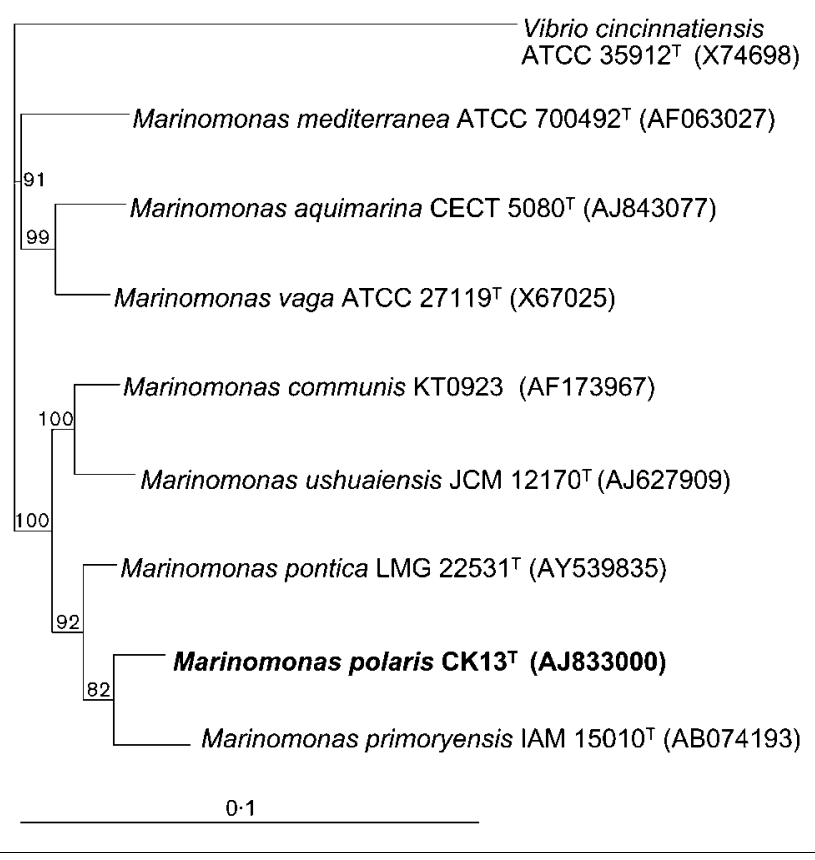

Fig. 1. Neighbour-joining tree based on 16S rRNA gene sequences (1475 bp) showing the phylogenetic relationship between Marinomonas polaris $\mathrm{CK}_{1}{ }^{\top}$ and related species of the genus Marinomonas. Bootstrap values (expressed as percentages of 1000 replications) greater than $50 \%$ are given at nodes. Vibrio cincinnatiensis was used as an outgroup. Bar, 0.1 nucleotide substitutions per nucleotide position.

from these two Marinomonas species, should be classified as a member of the genus Marinomonas. It is concluded that strain $\mathrm{CK} 13^{\mathrm{T}}$ represents a novel species, for which the name Marinomonas polaris sp. nov. is proposed.

\section{Description of Marinomonas polaris sp. nov.}

Marinomonas polaris (po.la'ris. N.L. fem. adj. polaris polar, referring to the origin of the type strain).

Cells are Gram-negative, motile, rod-shaped and are 0.6$0 \cdot 8 \mu \mathrm{m}$ wide and $2-3 \cdot 2 \mu \mathrm{m}$ in length. On marine agar, colonies are non-pigmented, cream, circular, raised, smooth and $2-3 \mathrm{~mm}$ in diameter. Grows between 4 and $37^{\circ} \mathrm{C}$ and with $0-11 \%$ salt in the medium. The optimum $\mathrm{pH}$ and salt concentration for growth are $\mathrm{pH} 7 \cdot 0$ and $5 \%$ salt, respectively. $\mathrm{CK} 13^{\mathrm{T}}$ tests positive for phosphatase, catalase, $\beta$ galactosidase, aesculinase and arginine dihydrolase activities and for citrate utilization, but negative for gelatin hydrolysis, indole production and lipase and lysine decarboxylase activities. Negative reaction in the Voges-Proskauer test, does not reduce nitrate to nitrite and no denitrification. Produces acid from sucrose, D-maltose, D-mannose, Dxylose, D-ribose and D-fructose, but not from glucose, melibiose or rhamnose. Utilizes D-glucose, D-fructose, Dxylose, D-galactose, D-ribose, D-mannose, sucrose, lactose, D-maltose, D-sorbitol, inositol, erythritol, adonitol, glycerol, D-cellobiose, dextrin, acetate, D-glucuronic acid, sodium 
gluconate, sodium malonate, L-glycine, L-histidine, Lthreonine, L-arginine, L-asparagine and glutamine, but not L-sorbose, L-rhamnose, L-raffinose, D-arabinose, xylitol, glycogen, citrate, lactate, malate, succinate, butyrate, sodium formate, benzoate, $m$-hydroxybenzoate, 2-oxoglutarate, propionate, L-lysine, L-alanine, L-serine, cysteine, L-aspartic acid or L-glutamic acid as sole carbon sources. The type strain is sensitive to amikacin $(30 \mu \mathrm{g})$, ciprofloxacin $(30 \mu \mathrm{g})$, kanamycin $(30 \mu \mathrm{g})$, chloramphenicol $(30 \mu \mathrm{g})$, tobramycin $(10 \mu \mathrm{g})$, nitrofurantoin $(300 \mu \mathrm{g})$, vancomycin $(30 \mu \mathrm{g})$, ampicillin $(10 \mu \mathrm{g})$, tetracycline $(30 \mu \mathrm{g})$, streptomycin $(30 \mu \mathrm{g})$, erythromycin $(30 \mu \mathrm{g})$, lincomycin $(30 \mu \mathrm{g})$, penicillin $(30 \mu \mathrm{g})$, nalidixic acid $(30 \mu \mathrm{g})$, nitrofurantoin $(300 \mu \mathrm{g})$, chloramphenicol $(30 \mu \mathrm{g})$, gentamicin $(30 \mu \mathrm{g})$, cephatoxime $(30 \mu \mathrm{g})$, cefoperazone $(75 \mu \mathrm{g})$, cefazolin $(30 \mu \mathrm{g})$, oleandomycin $(15 \mu \mathrm{g})$, polymyxin B $(50 \mathrm{U})$, spectinomycin $(100 \mu \mathrm{g})$, tobramycin $(30 \mu \mathrm{g})$ and rifampicin $(30 \mu \mathrm{g})$, but resistant to bacitracin $(10 \mathrm{U})$. The predominant phospholipids are phosphatidylethanolamine and phosphatidylglycerol. Major cellular fatty acids are $\mathrm{C}_{14: 0}(1 \cdot 2 \%)$, anteiso $\mathrm{C}_{15: 0}(1 \cdot 2 \%)$, iso $\mathrm{C}_{16: 0}(18 \cdot 5 \%), \mathrm{C}_{16: 0}(6 \cdot 2 \%)$, $\mathrm{C}_{16: 1} \omega 7 c(26 \cdot 5 \%)$, anteiso $\mathrm{C}_{17: 0}(2 \cdot 5 \%), \mathrm{C}_{18: 0}(2 \cdot 4 \%)$ and $\mathrm{C}_{18: 1} \omega 7 c(40 \cdot 0 \%)$. The DNA G $+\mathrm{C}$ content is $41 \cdot 2 \mathrm{~mol} \%$.

The type strain, CK13 ${ }^{\mathrm{T}}\left(=\mathrm{MTCC} 6645^{\mathrm{T}}=\mathrm{DSM} 16579^{\mathrm{T}}=\right.$ JCM $12522^{\mathrm{T}}$ ), was isolated from coastal sea water collected from the subantarctic Kerguelen island.

\section{References}

Baumann, L., Baumann, P., Mandel, M. \& Allen, R. D. (1972). Taxonomy of aerobic marine eubacteria. J Bacteriol 3, 402-429.

Baumann, P., Gauthier, M. J. \& Baumann, L. (1984). Genus Alteromonas Baumann, Baumann, Mandel and Allen. In Bergey's Manual of Systematic Bacteriology, vol. 1, pp. 343-352. Edited by N. R. Krieg \& J. G. Holt. Baltimore: Williams \& Wilkins.

Bligh, E. G. \& Dyer, W. J. (1959). A rapid method of total lipid extraction and purification. Can J Biochem Physiol 37, 911-917.

Felsenstein, J. (1993). PHYLIP (phylogeny inference package), version 3.5c. Distributed by the author. Department of Genome Sciences, University of Washington, Seattle, USA.

Gupta, P., Reddy, G. S. N., Delille, D. \& Shivaji, S. (2004). Arthrobacter gangotriensis sp. nov. and Arthrobacter kerguelensis sp. nov. from Antarctica. Int J Syst Evol Microbiol 54, 2375-2378.

Ivanova, E. P., Zhukova, N. V., Svetashev, V. I., Gorshkova, N. M., Kurilenko, V. V., Frolova, G. M. \& Mikhailov, V. V. (2000). Evaluation of phospholipid and fatty acid compositions as chemotaxonomic markers of Alteromonas-like proteobacteria. Curr Microbiol 41, 341-345.

Ivanova, E. P., Onyshchenko, O. M., Christen, R., Lysenko, A. M., Zhukova, N. V., Shevchenko, L. S. \& Kiprianova, E. A. (2005).
Marinomonas pontica sp. nov., isolated from the Black Sea. Int J Syst Evol Microbiol 55, 275-279.

Kimura, M. (1980). A simple method for estimating evolutionary rates of base substitutions through comparative studies of nucleotide sequences. J Mol Evol 16, 111-120.

Kiran, M. D., Prakash, J. S. S., Annapoorni, S., Dube, S., Kusano, T., Okuyama, H., Murata, N. \& Shivaji, S. (2004). Psychrophilic Pseudomonas syringae required trans-monounsaturated fatty acid for growth at higher temperature. Extremophiles 8, 401-410.

Macian, M. C., Arahal, D. R., Garay, E. \& Pujalte, M. J. (2005). Marinomonas aquamarina sp. nov., isolated from oysters and sea water. Syst Appl Microbiol 28, 145-150.

Prabagaran, S. R., Suresh, K., Manorama, R., Delille, D. \& Shivaji, S. (2005). Marinomonas ushuaiensis sp. nov., isolated from coastal sea water in Ushuaia, Argentina, sub-Antarctica. Int J Syst Evol Microbiol 55, 309-313.

Romanenko, A. L., Uchino, M., Mikhailov, V. V., Zhukova, N. V. \& Uchimura, T. (2003). Marinomonas primoryensis sp. nov., a novel psychrophile isolated from coastal sea-ice in the Sea of Japan. Int J Syst Evol Microbiol 53, 829-832.

Sato, N. S. \& Murata, N. (1988). Membrane lipids. Methods Enzymol 167, 251-259.

Shivaji, S., Ray, M. K., Saisree, L., Jagannadham, M. V., Seshu Kumar, G., Reddy, G. S. N. \& Bhargava, P. M. (1992). Sphingobacterium antarcticus sp. nov. a psychrotrophic bacterium from the soils of Schirmacher Oasis, Antarctica. Int J Syst Bacteriol 42, 102-116.

Shivaji, S., Bhanu, N. V. \& Aggarwal, R. K. (2000). Identification of Yersinia pestis as the causative organism of plague in India as determined by $16 \mathrm{~S}$ rDNA sequencing and RAPD-based genomic fingerprinting. FEMS Microbiol Lett 189, 247-252.

Smibert, R. \& Krieg, N. R. (1994). Phenotypic characterization. In Methods for General and Molecular Bacteriology, pp. 607-654. Edited by P. Gerhardt, R. G. E. Murray, W. A. Wood \& N. R. Krieg. Washington, DC: American Society for Microbiology.

Solano, F. \& Sanchez-Amat, A. (1999). Studies on the phylogenetic relationships of melanogenic marine bacteria: proposal of Marinomonas mediterranea sp. nov. Int J Syst Bacteriol 49, 1241-1246.

Stackebrandt, E. \& Goebel, B. M. (1994). Taxonomic note: a place for DNA-DNA reassociation and 16S rRNA sequence analysis in the present species definition in bacteriology. Int J Syst Bacteriol 44, 846-849.

Thompson, J. D., Higgins, D. G. \& Gibson, T. J. (1994). CLUSTAL W: improving the sensitivity of progressive multiple sequence alignment through sequence weighting, position-specific gap penalties and weight matrix choice. Nucleic Acids Res 22, 4673-4680.

Tourova, T. P. \& Antonov, A. S. (1987). Identification of microorganisms by rapid DNA-DNA hybridization. Methods Microbiol 19, 333-355.

Van Landschoot, A. \& De Ley, J. (1983). Intra- and intergeneric similarities of the rRNA cistrons of Alteromonas, Marinomonas (gen. nov.) and some other Gram-negative bacteria. J Gen Microbiol 129, 3057-3074. 